Article

\title{
Probabilistic and Fuzzy Approaches for Estimating the Life Cycle Costs of Buildings under Conditions of Exposure to Risk
}

\author{
Edyta Plebankiewicz ${ }^{1, *}$, Wiesław Meszek ${ }^{2}$, Krzysztof Zima ${ }^{1}$ and Damian Wieczorek ${ }^{1}$ \\ 1 Faculty of Civil Engineering, Cracow University of Technology, 31-155 Krakow, Poland; \\ kzima@17.pk.edu.pl (K.Z.); dwieczorek@17.pk.edu.pl (D.W.) \\ 2 Faculty of Civil and Environmental Engineering, Poznan University of Technology, 60-965 Poznan, Poland; \\ wieslaw.meszek@put.poznan.pl \\ * Correspondence: eplebank@L7.pk.edu.pl
}

Received: 4 December 2019; Accepted: 23 December 2019; Published: 26 December 2019

check for updates

\begin{abstract}
The paper discusses issues related to life cycle costs in construction. Life cycle cost is a key element in the assessment of environmental sustainability in construction and it provides a tool for the economic evaluation of alternative sustainability options exhibiting different capital, operating costs or resource usage. The authors reviewed selected models of estimating life cycle costs in construction, drew attention to the complex mathematical models developed so far, namely those which take into account only financial risks and those which involve the possibility of the influence of other risk factors and described the main assumptions accompanying the original model for estimating the whole life costs of buildings, including: reasons for choosing theory of possibility, division and parametrization of input data. The aim of this paper is to confirm the validity of the model structure assumptions adopted by the authors by comparing the originally selected fuzzy approach to calculating life cycle costs taking into account the risk with the probabilistic approach, as well as indicating the domain in which the probabilistic approach will complement the fuzzy approach chosen by the authors. The paper presents a comparison analysis of two approaches used in the authors' model, a fuzzy and a probabilistic approach, recommended by the ISO standard 15686-5:2008. The authors used the Oracle Crystall Ball software in their simulations.
\end{abstract}

Keywords: life cycle costs; whole life costs; risk; cost addition for risk; probabilistic approach; fuzzy approach; certainty level; buildings

\section{Introduction}

Economic life cycle costs analysis (LCCA) is an increasingly common subject of consideration of scientists. As a result of the research conducted so far, several original methods or models for estimating life cycle costs in construction have been developed, both for LCCA for buildings and constructed assets [1-5], and for building materials and components [6-9]. Moreover, the methods used in the economic calculation to compare the financial outlays were subject to certain modifications, which enabled their adaptation to the needs of LCCA implementation [6,10-14]. It is also noted that the issue of LCCA is raised in contemporary publications dealing with the development of Building Information Modelling (BIM) technology for building operation, which would include planning renovation, refurbishment and inspection procedures and maintenance activities, using 7D BIM tools based on product life cycle management (PLM) [15].

In general, the LCCA can be performed using the so-called simple or complex method. The application of the simple method is appropriate only in the case of simple comparisons which 
serve to select the optimal variant of the construction project execution, but only in cases where the period of its exploitation is not too long. The main disadvantage of the simple method is the fact that in the calculations the phenomenon of money value changes over time and changes in energy prices are omitted. The second approach to estimating life cycle costs in construction is a complex one. The complex approach (as opposed to the simple approach) allows financial risks to be taken into account by analysing the change in the value of money over time. The application of advanced mathematical techniques and tools (such as fuzzy logic, genetic algorithms and probabilistic methods) enables the analysis of the impact of other risk factors which can also be identified in the life cycle of the building [16].

It is worth noting that the estimation of life cycle costs is a calculation, therefore the calculated value of LCC should include the impact of the risk involved. This basic issue is addressed by ISO standard 15686-5:2008 buildings and constructed assets; service life planning; part 5: life-cycle costing [11]. There are a lot of studies concerning the impact of risk factors on the building life cycle costs, but as the standard states in Section 8, none of the models defines or expresses the impact of risk in the form of a separately quantified cost addition for the risk (8.1. section of [11]).

Taking into account the above, the authors attempted to develop a complex model for estimating the whole life costs of buildings, which enables the quantification of cost addition for risk, and which allows the investor to compare buildings in terms of a number of economic criteria, namely: life cycle costs (LCC - when the investor cannot record incomes), whole life costs (WLC — when, in addition to incurring costs in the phases of the building life cycle, the investor will also be able to record incomes), life cycle equivalent annual costs (LCEAC — when the durations of the exploitation phase differ) and cost addition for risk $\left(\triangle \mathrm{R}_{\mathrm{LCC}}\right.$-expressed as a difference in currency units between the amount of the life cycle cost of a building which takes into account the impact of risk, and the value of the life cycle cost of a building that does not respect this influence). The authors based the assumptions of the model on the fuzzy approach, and the subsequent stages of the model development are treated by their numerous publications [17-20], including the publications on verification studies investigating the correctness of the model's operation [21,22].

The aim of this paper, however, is an attempt to confirm the validity of the model structure assumptions adopted by the authors by comparing the originally selected fuzzy approach to calculating life cycle costs taking into account the risk with the probabilistic approach, as well as indicating the domain in which the probabilistic approach will complement the fuzzy approach chosen by the authors. What is more, the probabilistic approach is recommended by the ISO standard (Section 8.3 of [11]) due to the need to conduct LCCA in conditions of uncertainty or risk taking into account statistical methods, such as the Monte Carlo analysis at the level of probability reaching 10\%, 50\%, and 90\%.

In their simulations, the authors used the following software: Oracle Crystall Ball that is the leading spreadsheet-based application for predictive modeling, forecasting, simulation, and optimization in situations where critical risk factors can be affected.

\section{Selected Models for Estimating Life Cycle Costs Involving Risk Impact-A Literature Review}

In the literature on the subject one can distinguish complex models which involve only the influence of financial risk and those which, apart from financial risk, take into account the influence of other risk factors in the life cycle of building materials and components or buildings and constructed assets.

Table 1 presents a selection of complex mathematical models prepared for estimation of life cycle costs in the construction industry, whose authors took into account the financial risk in the form of money value change over time. 
Table 1. Complex approach involving financial risk - the estimated cost elements in the selected cases of life cycle costs analysis (LCCA) analyses in the construction industry (own study).

\begin{tabular}{|c|c|c|c|}
\hline $\begin{array}{l}\text { Authors, Year and the } \\
\text { Subject of Study }\end{array}$ & Type of Approach & Cost Elements & $\begin{array}{l}\text { Main Aim of the } \\
\text { Analysis }\end{array}$ \\
\hline \multicolumn{4}{|c|}{ Building Materials and Components } \\
\hline $\begin{array}{c}\text { Zayed, Chang and } \\
\text { Fricker, } 2002[6] \\
\text { Paint coatings on steel } \\
\text { bridges }\end{array}$ & $\begin{array}{l}\text { Deterministic, including } \\
\text { the net present value and } \\
\text { equivalent annual costs }\end{array}$ & $\begin{array}{l}\text { Initial costs and costs } \\
\text { incurred during the } \\
\text { utilization of paint } \\
\text { coatings }\end{array}$ & $\begin{array}{l}\text { Cost comparison for } \\
\text { three alternative coating } \\
\text { maintenance strategies, } \\
\text { that is maintenance, } \\
\text { on-site repairs and } \\
\text { repainting }\end{array}$ \\
\hline $\begin{array}{c}\text { Noor and Aizuddin, } \\
2013 \text { [7] } \\
\text { Floor coverings in public } \\
\text { buildings }\end{array}$ & $\begin{array}{l}\text { Deterministic, based on } \\
\text { an economic model, } \\
\text { taking into account the } \\
\text { quality of building } \\
\text { components, } \\
\text { construction, operation } \\
\text { and maintenance }\end{array}$ & $\begin{array}{l}\text { Initial construction costs } \\
\text { and the sum of all costs } \\
\text { relating to maintenance, } \\
\text { repair, as well as the } \\
\text { annual costs of staff and } \\
\text { taxes }\end{array}$ & $\begin{array}{l}\text { Determination of the } \\
\text { influence of individual } \\
\text { factors on costs, } \\
\text { construction of the most } \\
\text { favourable result }\end{array}$ \\
\hline \multicolumn{4}{|c|}{ Buildings and Constructed Assets } \\
\hline $\begin{array}{c}\text { Aye, Bamford, Charters } \\
\text { and Robinson, } 2000 \text { [10] } \\
\text { Office and commercial } \\
\text { buildings }\end{array}$ & $\begin{array}{l}\text { Deterministic, based on } \\
\text { an economic feasibility } \\
\text { study, using a discount } \\
\text { account to reflect the } \\
\text { change in money value } \\
\text { over time }\end{array}$ & $\begin{array}{l}\text { Initial construction costs, } \\
\text { operating costs, } \\
\text { including energy } \\
\text { demand and withdrawal } \\
\text { costs }\end{array}$ & $\begin{array}{l}\text { Comparison and } \\
\text { identification of the best } \\
\text { of the four preferred } \\
\text { alternatives in terms of } \\
\text { life cycle costs }\end{array}$ \\
\hline $\begin{array}{c}\text { Hasan, Vuolle and Siren, } \\
2008 \text { [12] } \\
\text { Detached houses }\end{array}$ & $\begin{array}{l}\text { Deterministic, using } \\
\text { simulation and economic } \\
\text { optimization methods to } \\
\text { calculate cost differences } \\
\text { in the building life cycle } \\
\text { costs }\end{array}$ & $\begin{array}{l}\text { Investment and } \\
\text { operating costs, } \\
\text { including maintenance } \\
\text { and replacement costs }\end{array}$ & $\begin{array}{c}\text { Comparison of } \\
\text { calculated cases and } \\
\text { minimization of building } \\
\text { life cycle costs }\end{array}$ \\
\hline $\begin{array}{l}\text { Marszal and Heiselberg, } \\
2011 \text { [13] } \\
\text { Residential, multi-storey } \\
\text { buildings with zero } \\
\text { energy demand }\end{array}$ & $\begin{array}{l}\text { Deterministic, including } \\
\text { the net present value and } \\
\text { equivalent annual costs }\end{array}$ & $\begin{array}{l}\text { Investment, operating } \\
\text { and demolition costs } \\
\text { including revenues from } \\
\text { renewable energy } \\
\text { systems }\end{array}$ & $\begin{array}{l}\text { Determine the value of } \\
\text { life cycle costs and } \\
\text { choose the optimal } \\
\text { solution from a variety of } \\
\text { alternatives }\end{array}$ \\
\hline $\begin{array}{c}\text { Plebankiewicz, } 2014 \text { [14] } \\
\text { Urban buildings }\end{array}$ & $\begin{array}{l}\text { Deterministic, based on } \\
\text { the analysis of the net } \\
\text { present value and } \\
\text { economic efficiency of } \\
\text { the investment, taking } \\
\text { into account } \\
\text { environment protection } \\
\text { issues }\end{array}$ & $\begin{array}{l}\text { Initial costs for land } \\
\text { acquisition, design and } \\
\text { construction of the } \\
\text { building, as well as } \\
\text { maintenance and } \\
\text { operating costs }\end{array}$ & $\begin{array}{l}\text { Comparison and } \\
\text { selection of the best } \\
\text { alternative solution in } \\
\text { terms of environmental } \\
\text { and economic criteria }\end{array}$ \\
\hline
\end{tabular}

The complex methods described in Table 1 are based mainly on economic models that take into account the phenomenon of money value change over time, and thus correspond to the analysis of the potential impact of the occurrence of financial risk on the amount of future costs, as related to the present day.

An example of complex methods is the one implemented by the Finnish team, Hasan, Vuolle and Siren, for single-family detached houses [12]. The authors considered a building designed in terms of structure and installation to be the basis for the analysis, which they call a reference case. For the reference case, design alternatives are then prepared, which are related to a small scope of modifications of construction solutions concerning the type and system of window joinery used, thermal insulation of 
horizontal and vertical partitions, or electrical installations, as well as the scope of design modifications in terms of HVAC installation systems (HVAC: acronym of heating, ventilation, air conditioning) which are responsible for controlling the heating, ventilation and air conditioning of the building. As a result of this approach, it is not necessary for the analysis to include any cost data on all the construction components of the building or the installation systems designed for every alternative solution, since a considerable number of them are the same as for the reference case. Therefore, for any alternative solution, the value of life cycle costs are not calculated from scratch but on the basis of the data related to the extent of modifications made only, which will result in differences in the magnitude of the corresponding cost components.

The most common example of a complex method is the one analysing the effectiveness of a construction project based on discounted cash flows of net present value in the life cycle (LCNPV). This method applied, for example, by $[12,14]$ makes it possible to assess the construction project on the basis of the life cycle cost criterion and, at the same time, to compare and select (from among alternative variants of the project) such a variant which meets both the economic and environmental criteria. The $L C N P V$ value is calculated by the following equation:

$$
L C N P V=\sum_{i=0}^{n} \frac{C F_{i}}{(1+r)^{i}}
$$

where $C F_{i}$ is cash flow in $i$-th year, $\mathrm{n}$ is life cycle duration in years, $i$ is subsequent year, $r$ is discount rate.

The number of mathematical models developed for the estimation of life cycle costs in construction, in which authors considered the possibility of the impact of risk factors other than financial ones, is no longer so large. The following presents examples of models and researchers that developed or adapted them.

Fuller and Boyles [23] use probabilistic techniques that help analyze risks that may also accompany heat pump-based installation systems (for instance, the risk of equipment failure or the risk of achieving lower energy gains than originally assumed). The cost elements that have been taken into account in the studies are the initial costs of purchasing the installation, the annual electricity consumption costs and the annual operating costs (including maintenance) of the equipment. The analysis also takes into account the amount of energy gains and the residual value from the resale of some of the components of the installation system. The authors use the Monte Carlo analysis as a simple technique for taking samples of probability distributions for uncertain input values so that results close enough to the correct probability distribution can be obtained. Based on the information about the likelihood of the risk factor, a decision is made to include additional costs in the life cycle cost of a building or to reduce the energy gains relating to the revenues over its life cycle.

Menassa [24] outlines the ways to determine life cycle costs for construction projects involving the upgrading of existing buildings in the context of sustainable development. The author considers risk factors that he attributes to technological nature (design errors, incompatibility of characteristics of building materials with design assumptions, variable productivity of construction workers), business (unpredictability of market changes, volatility in tax systems) and political (changes in environmental regulations, limiting the possibility of using raw materials or building materials on local markets). In the author's opinion, the risk factors listed may occur in the construction projects in question and may also have a negative impact on the size of life cycle costs of buildings. In his research, the author combines a probabilistic approach to risk analysis in the context of economic assessment of the effectiveness of construction projects. The author uses economic indicators in his work, such as minimum attractive rate of return (MARR) and net present value (NPV).

Ammar, Zayed and Mosehli [25] assess design alternatives for structural elements of buildings with varying operating times. As a comparative criterion, the authors propose equivalent annual cost for building (EAC) as an index. The analysis takes into account initial costs, annual maintenance costs and the costs of building decommissioning. In addition, each cost type considers the impact of risks on 
their value, though the authors do not mention the particular names of the risk factors. The category or nature of the risk is also not specified. In their work, the authors apply the theory of fuzzy sets, the DSW (Dong, Shah and Wong) algorithm, which simplifies the basic arithmetic operations on fuzzy numbers and the vertex method, which allows to eliminate errors that may occur during arithmetic operations on fuzzy numbers after their previous decomposition. In their publication, the authors also check the correctness of the model operation on the example of water supply networks and sewage infrastructure modernization projects [26].

\section{Original Model for Estimating the Whole Life Costs of Buildings}

\subsection{Reasons for Choosing Theory of Possibility to Build the Model}

Many researchers [27-37] and ISO standard [11] state that in some publications the terms risk and uncertainty are treated identically or interchangeably, which is a mistake. According to Knight [28] and ISO standard [11], risk is related to the so-called measurable uncertainty. The measurable nature of uncertainty results from the fact that risk is quantifiable and can be directly translated into the size of parameters necessary, for example, to perform an economic efficiency calculation for a planned construction project.

Two ways of describing measurable uncertainty are commonly used, namely the probability theory and probability distributions, as well as the theory of fuzzy sets and the so-called possibility distributions. As a number of studies reveal, such as [38-42]:

- the developed concepts of risk quantification which concern (in general) investment projects, assume a probabilistic character of a description of uncertainty of parameters necessary, for instance, to perform an economic efficiency calculation or risk assessment, but in some cases this assumption is not correct,

- in practice, it happens that the expert assessing the risk does not have at his or her disposal a sufficient number of data enabling statistical research to be performed, from which a probabilistic probability distribution would result, and thus he or she subjectively determines the size of parameters necessary, for example, to perform an economic efficiency calculation,

- rapid changes in market conditions are also frequent and may be contradictory to the forecasts used in the parameterization of variables which are often based on historical data,

- it is also possible to indicate cases in which the nature of uncertainty of parameters that are necessary, for instance, to perform an economic efficiency calculation, cannot be linked to a probability account because it is related to a unique, often one-off, event,

- it is more natural for humans to describe the uncertainty of parameters necessary, for example, to perform an economic efficiency calculation or risk assessment, by means of linguistic variables (phenomena verbally described), which may correspond to expert estimates categorized as most favourable, average and the worst variants of the parameter in question.

In view of this argument, the structure of the model for estimating the whole life costs of buildings, is going to be based on the theory of possibility, and thus on fuzzy logic.

\subsection{Main Assumptions of the Model}

As indicated in the authors' publications [20,22], in the model for estimating the whole life costs of buildings allowing quantification of the cost allowance for risk, the fuzzy set theory is combined with a method used to analyze the economic efficiency of construction projects based on discounted cash flows (dCF). This is the net present worth method (NPW), which in the model for estimating the whole life costs of buildings is applicable in a fuzzy version (the fuzzy NPW method). The model calculation path is based on:

- the analysis of discounted cash flows $(\mathrm{dCF})$ at a specified value discount rate (r), 
- net present worth (NPW) index, which means the difference between discounted cash flows (dCF) and initial investment expenditure (investment),

- the concept of a fuzzy number,

- theorem on the decomposition of a fuzzy set into $\alpha$-cuts,

- Zadeh's principle of fuzzy extension.

A set of calculation formulas which enable the calculation of economic indexes, LCC, WLC, LCEAC and $\triangle \mathrm{R}_{\mathrm{LCC}}$, was presented and discussed in detail in the following publications [17-20]. Only the most important equations by which the values of the indexes are calculated are listed below, namely LCC (according to Equation (2)) and WLC, which is the difference between the values of LCC (Equation (2)) and incomes in the building life cycle, ILC (Equation (3)):

$$
\overline{L C C_{i}}=\overline{C_{i n, i}}+\overline{P W F_{A C, i}} \cdot \sum_{j=1}^{n_{A C, i}} \overline{C_{o p A, i j}}+\sum_{k=1}^{n_{N A C, i}} \overline{C_{o p N A, i k}} \cdot \overline{P W F_{N A C, i k}}+\overline{P W F_{W D, i}} \cdot \overline{C_{w d, i}}
$$

where $L C C_{i}$ is the life cycle cost of the $\mathrm{i}$-th building, $C_{i n, i}$ is the amount of initial costs, $C_{o p A, i j}$ is the amount of the $\mathrm{j}$-th annual operating cost, $C_{o p N A, i k}$ is the amount of the k-th periodical operating cost, $C_{w d, i}$ is the amount of the withdrawal costs, $n_{A C, i}, n_{N A C, i}$ is number (multiple) of annual and periodical operating costs, respectively, $P W F_{A C, i}$ is value of the discount factor for annual operating costs, $P W F_{N A C, i k}$ is value of the discount factor for the $\mathrm{k}$-th periodical operating cost, $P W F_{W D, i}$ is the value of the discount factor for the revenue generated in the withdrawal phase, where an overbar in the formula means that the value is a fuzzy number.

$$
\overline{I L C}=\overline{P W F_{A I, i}} \cdot \sum_{l=1}^{n_{A I, i}} \overline{I_{o p A, i l}}+\sum_{m=1}^{n_{N A I, i}} \overline{I_{o p N A, i m}} \cdot \overline{P W F_{N A I, i m}}+\overline{P W F_{W D I, i}} \cdot \overline{I_{w d, i}}
$$

where $I L C_{i}$ is the amount of incomes in the life cycle of the $i$-th building, $I_{o p A, i l}$ is the amount of l-th annual income, $I_{o p N A i, m}$ is the amount of the $m$-th periodical income, $I_{w d, i}$ is the amount of income reached in the withdrawal phase, $n_{A I, i}, n_{N A I, i}$ is number (multiple) of operational incomes of annual and periodic nature, respectively, $P W F_{A I, i}$ is value of the discount rate for annual incomes, $P W F_{N A I, i m}$ is value of the discount rate for the periodical $\mathrm{m}$-th income, $P W F_{W D, i}$ is the value of the discount factor for the income earned in the retirement phase; where an overbar in the formula means that the value is a fuzzy number.

The value of the LCEAC index is the product of the LCC value multiplied by the annual discount factor (AF-annuity factor) which is calculated on the basis of Equation (4):

$$
\overline{A F_{i}}=\frac{\bar{r} \cdot(1+\bar{r})^{\overline{T_{i}}}}{(1+\bar{r})^{\overline{T_{i}}}-1}
$$

where $r$ is discount rate, $T_{i}$ is life cycle of the $i$-th building (equal to the operating period of the building); where an overbar in the formula means that the value is a fuzzy number.

The index of cost addition for risk $\left(\Delta \mathrm{R}_{\mathrm{LCC}}\right)$ is calculated as the difference between the life cycle costs of a building which involves the impact of risk (LCC) and the life cycle costs of a building which does not take this impact into account ( $\mathrm{LCC}^{\mathrm{REF}}$ ). Both values listed here (LCC, $\mathrm{LCC}^{\mathrm{REF}}$ ) is calculated by means of Equation (2).

\subsection{Division and Parameterization of Input Data to the Model}

Input data for the model estimating the whole life costs of buildings are subdivided into the following parameters: 
- TG (temporal-global)-temporal (of a global nature), that is the life cycle of the $T_{i}$ building, where $T_{i}$ equals the estimated service life of a building (ESLB),

- $\quad$ TL (temporal-local)—temporal (of a local nature), that is times $t_{i k}, t_{i m}$, after which $\mathrm{k}$-th periodic operating costs or $\mathrm{m}$-th periodic income are calculated, respectively,

- FG (financial-global) - financial (of a global nature), in the form of a discount rate ( $r$ ) which is necessary to calculate the net present value of a particular amount of money on the basis of its value specified at a future date,

- FC (financial-costs) - financial (understood as costs that may occur during the life cycle of a building) including costs of an annual nature: annual operating costs $C_{o p A, i j}$, and periodical: successively, initial costs $C_{i n, i}$, periodical operating costs $C_{o p N A, i k}$ and withdrawal costs $C_{w d, i}$,

- FI (financial-incomes) - financial (understood as costs that may occur during the life cycle of a building), that is incomes of an annual nature: annual $I_{o p A, i l}$, and periodical: successively, periodical incomes obtained during the operating phase of the building $I_{o p N A, i m}$ and incomes reached during the withdrawal phase $I_{w d, i}$.

Convex and normal fuzzy numbers are used for the parameterization of the above mentioned data. Figure 1 presents the basic set of membership functions of fuzzy numbers (functions with line segment graph) for the input data without risk (Figure 1a), for discount rate (Figure 1b) and for temporal parameters TG and TL, and for financial FC and FI where the impact of risk on the amount of the parameter concerned will be taken into account (Figure 1c,d).
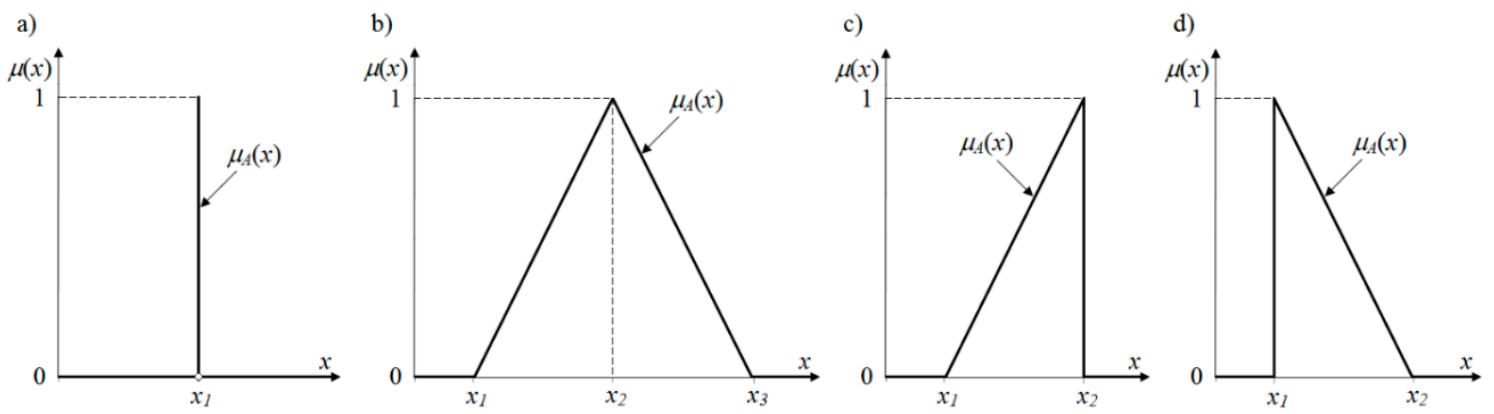

Figure 1. Fuzzy number membership functions for input parameters: (a) for the input data without risk; (b) for discount rate; (c,d) for the input data TG (temporal-global), TL (temporal-local), FC (financial-costs) and FI (financial-incomes) where the impact of risk on the amount of the parameter concerned will be taken into account-basic set (own study).

The remaining sets of fuzzy number membership functions, including functions with square segmented graphs (alternative set I), harmonic functions (alternative set II) and complex symmetrical and asymmetrical functions of Gauss (alternative set III) are presented in Figures 2-4, respectively.
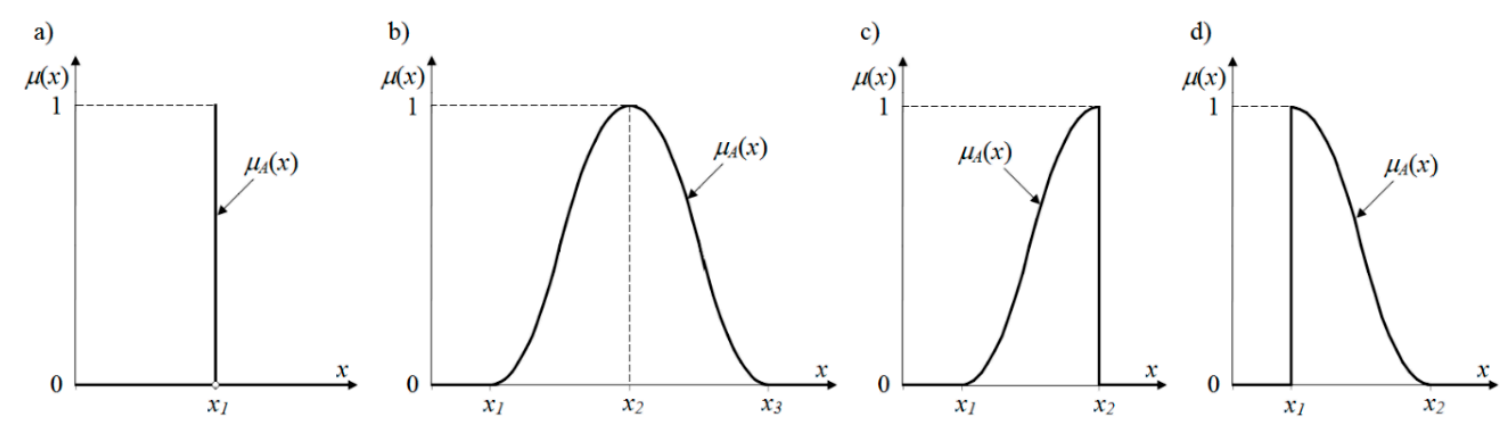

Figure 2. Fuzzy number membership functions for input parameters: (a) for the input data without risk; (b) for discount rate; (c,d) for the input data TG, TC, FC and FI where the impact of risk on the amount of the parameter concerned will be taken into account-alternative set I (own study). 

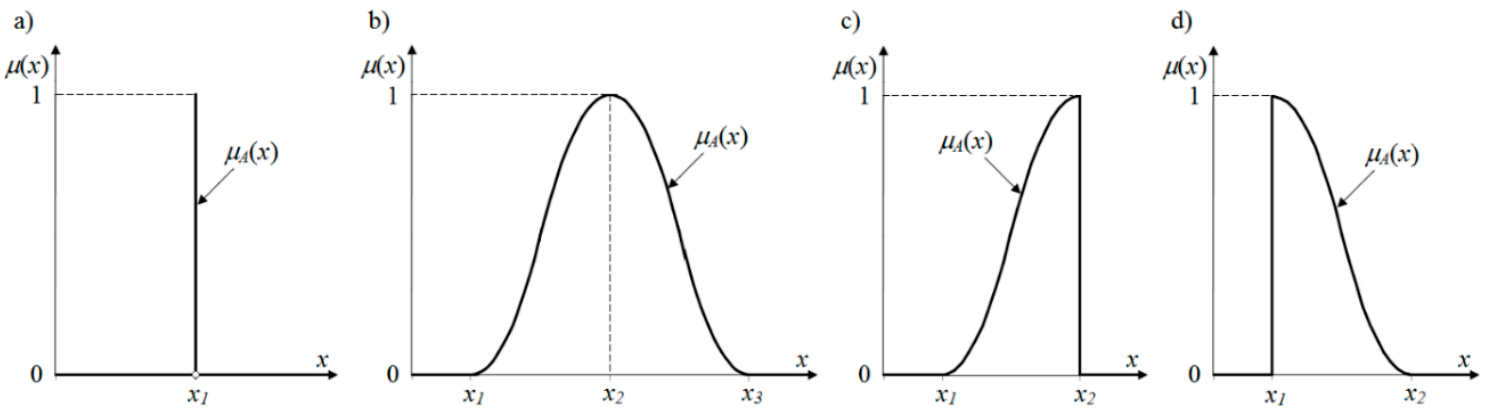

Figure 3. Fuzzy number membership functions for input parameters: (a) for the input data without risk; (b) for discount rate; (c,d) for the input data TG, TC, FC and FI where the impact of risk on the amount of the parameter concerned will be taken into account-alternative set II (own study).
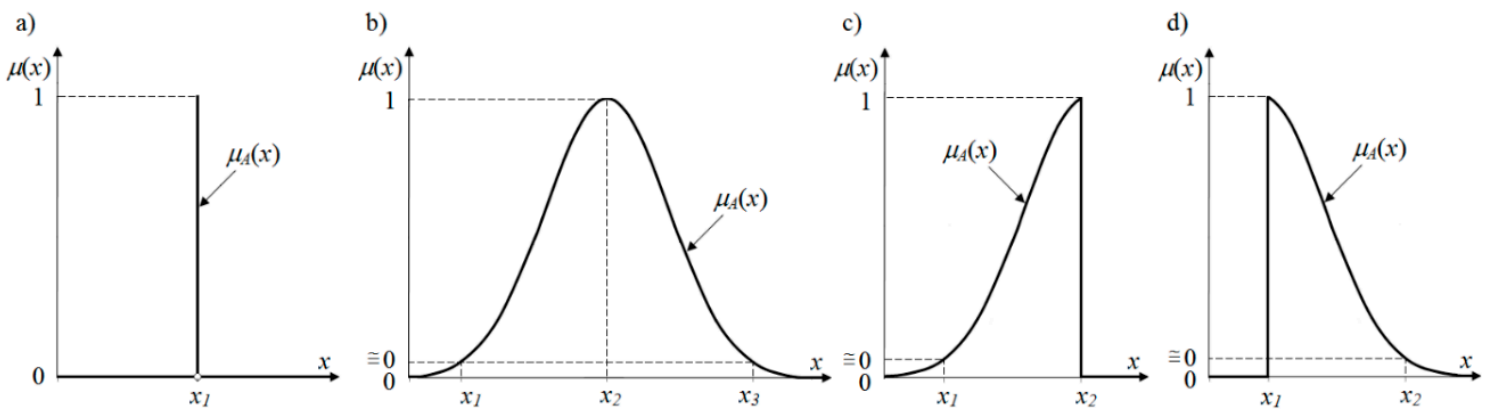

Figure 4. Fuzzy number membership functions for input parameters: (a) for the input data without risk; (b) for discount rate; (c,d) for the input data TG, TC, FC and FI where the impact of risk on the amount of the parameter concerned will be taken into account-alternative set III (own study).

The possibilities of using alternative sets of fuzzy number membership functions are described by [22].

\section{Life Cycle Cost Analysis-Comparison of Results Obtained by the Fuzzy and Probabilistic Approach}

\subsection{LCCA with Use of Fuzzy Approach and the Model for Estimating the Whole Life Costs of Buildings}

The computational example refers to a multi-family residential building for which an economic life cycle costs analysis (LCCA) was performed on the basis of the life cycle costs (LCC) criterion. The following assumptions were made in the example:

- the considered financial risk factor is related to the possibility of a change in the discount rate (r) between $6 \%$ and $10 \%$ (with a forecast average value of $8 \%$, using triangular membership function, as in Figure 1b),

- the adopted type of building maintenance consists in preventive maintenance in accordance with the ISO standard [11], with an average allocation of financial resources for current maintenance and periodic repairs of the building at the stage of its operation,

- it is assumed that the life cycle of the building would end with its demolition and the resale of the building plot on which it was built (building life cycle termination of the "from cradle to grave" type, in accordance with the ISO standard [11]).

Table 2 presents the values of input parameters (time and financial ones) adopted for the LCCA analysis. 
Table 2. Input data accepted for the life cycle costs analysis (LCCA) analysis (own study).

\begin{tabular}{|c|c|c|}
\hline \multicolumn{2}{|l|}{ Parameters } & Values \\
\hline \multicolumn{2}{|l|}{ Life cycle $\left(T_{i}=\right.$ ESLB $)$} & 50 years \\
\hline \multicolumn{2}{|l|}{ Discount rate $(r)$} & about $8 \%$ \\
\hline \multicolumn{2}{|l|}{ Initial costs $\left(C_{i n, i}\right)$} & 1,675,837 EUR \\
\hline \multicolumn{2}{|l|}{ Annual operating costs $\left(C_{o p A, i j}\right)$} & 23,581 EUR \\
\hline \multirow{5}{*}{$\begin{array}{l}\text { Periodical operating costs }\left(C_{o p N A, i k}\right) \text { after } \\
\text { the time of }\left(t_{i k}\right)=\ldots\end{array}$} & 10 & 52,884 EUR \\
\hline & 20 & 52,884 EUR \\
\hline & 30 & 211,558 EUR \\
\hline & 40 & 52,884 EUR \\
\hline & 50 & not applicable \\
\hline \multicolumn{2}{|c|}{ Withdrawal costs $\left(C_{w d, i}\right)$ after the time of $\left(T_{i}=\right.$ ESLB $)$} & 121,256 EUR \\
\hline
\end{tabular}

ESLB $=$ estimated service life of a building.

Figure 5 presents a graph of the results obtained for the economic criterion of life cycle costs (LCC) for the basic membership functions (functions with line segment graphs).

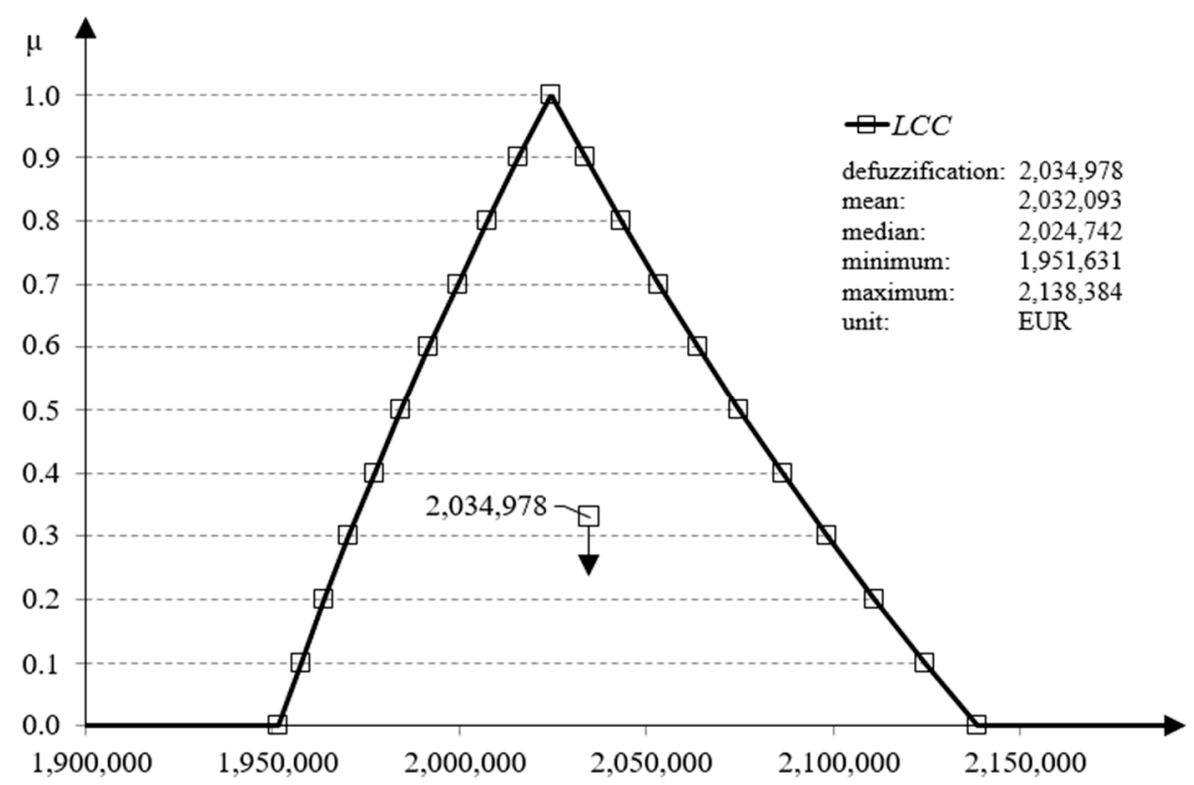

Figure 5. Resulting membership distributions for the LCC criterion-basic set (own study).

The LCCA analysis shows that for the criterion of life cycle costs (LCC) in accordance with the fuzzy approach:

- defuzzification value (calculated with use of the center of gravity method) equals 2,034,978 EUR,

- mean value is 2,032,093 EUR,

- median is equal to $2,024,742 \mathrm{EUR}$,

- minimum value equals $1,951,631$ EUR,

- $\quad$ maximum value is $2,138,384$ EUR.

\subsection{LCCA with Use of Probabilistic Approach and Oracle Crystall Ball Software}

In accordance with the assumptions adopted for the example discussed in Section 4.1 and taking into account the values of input parameters (temporal and financial) adopted for LCCA in this chapter (Table 2), the authors simulated calculations of the life cycle costs (LCC) criterion based on a probabilistic approach. 
Figure 6 presents the triangular distribution of the discount rate parameter (r) which was used for the calculation according to the same assumptions as in the fuzzy approach, and which was modelled using Oracle Crystall Ball software.

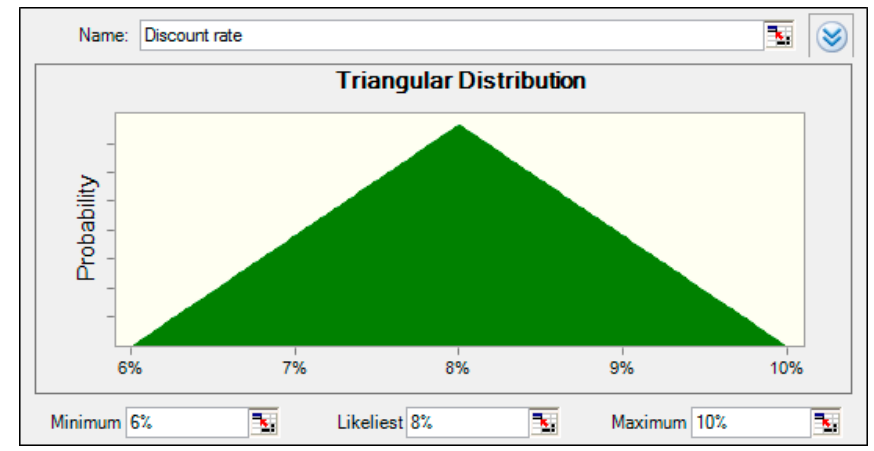

Figure 6. Triangular distribution of the discount rate parameter- $r$ (own study).

Figure 7 presents the results obtained in Oracle Crystall Ball software for the economic criterion of life cycle costs (LCC) in a probabilistic perspective. Figure 7 reveals certainty level values and the LCC result range for the cross-section corresponding to the 0.5 cross-section, according to the fuzzy approach. The result was a certainty level of $74.9583 \%$ and in the results range from EUR 1,985,363 to EUR 2,077,267.

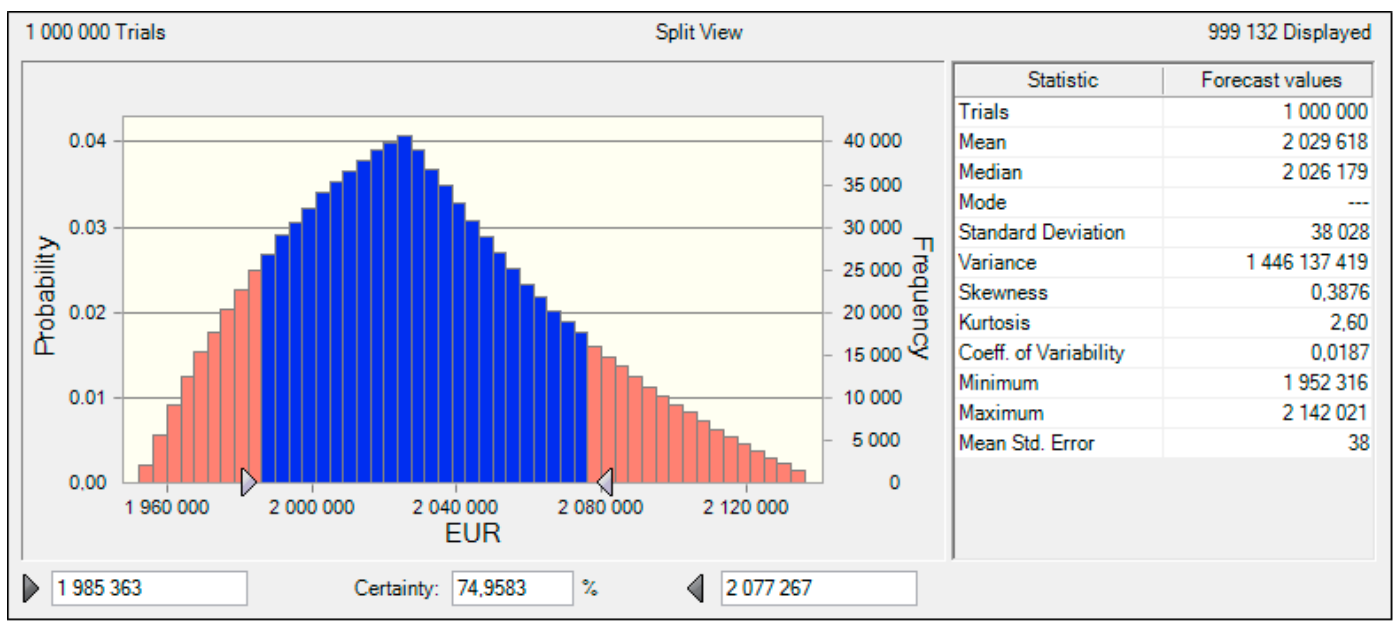

Figure 7. LCCA-probabilistic approach for the cross-section corresponding to the 0.5 cross-section, according to the fuzzy approach (own study).

The LCCA analysis shows that for the criterion of life cycle costs (LCC), in accordance with probabilistic approach:

- mean value is $2,029,618 \mathrm{EUR}$,

- median is equal to 2,026,179 EUR,

- minimum value equals 1,952,316 EUR,

- $\quad$ maximum value is $2,142,021$ EUR.

\subsection{LCCA-Comparison of Results Obtained using the Fuzzy and Probabilistic Approach}

Table 3 illustrates a summary of the LCCA results described in Sections 4.1 and 4.2, which were subjected to a comparative analysis. The columns indicating differences (in EUR and in percent) present the differences in relation to the result obtained according to the fuzzy approach. 
Table 3. Results of the comparative analysis of the fuzzy and probabilistic approaches to LCCA (own study).

\begin{tabular}{ccccc}
\hline \multirow{2}{*}{ Parameter (Value) } & \multicolumn{2}{c}{ LCC Results (in EUR) According to } & \multicolumn{2}{c}{ Differences } \\
& A Fuzzy Approach & A Probabilistic Approach & EUR & $\%$ \\
\hline Defuzzification & $2,034,978$ & not applicable & - & - \\
Mean & $2,032,093$ & $2,029,618$ & -2475 & -0.122 \\
Median & $2,024,742$ & $2,026,179$ & +1437 & +0.071 \\
Minimum & $1,951,631$ & $1,952,316$ & +685 & +0.035 \\
Maximum & $2,138,384$ & $2,142,021$ & +3637 & +0.170 \\
\hline
\end{tabular}

As it results from the comparative analysis, the differences obtained for the LCCA results according to the probabilistic approach are very small in relation to the results calculated on the basis of the fuzzy approach. In the case of median and minimum values, the differences (in absolute value) equal less than $0.1 \%(|+0.071| \%$ and $|+0.035| \%$, respectively). The differences for mean and maximum values are slightly greater and amount to $|-0.122| \%$ and $|+0.170| \%$, respectively.

\subsection{Monte Carlo Analysis with use of Oracle Crystall Ball Software}

Figures 8-10 depict the successive ranges of results for the given certainty level of 10\%, 50\% and $90 \%$ respectively, that is in accordance with the recommendation of ISO (Section 8.3 of [11]) to perform LCCA in the situation of uncertainty or risk impact, taking into account statistical methods, such as the Monte Carlo analysis.

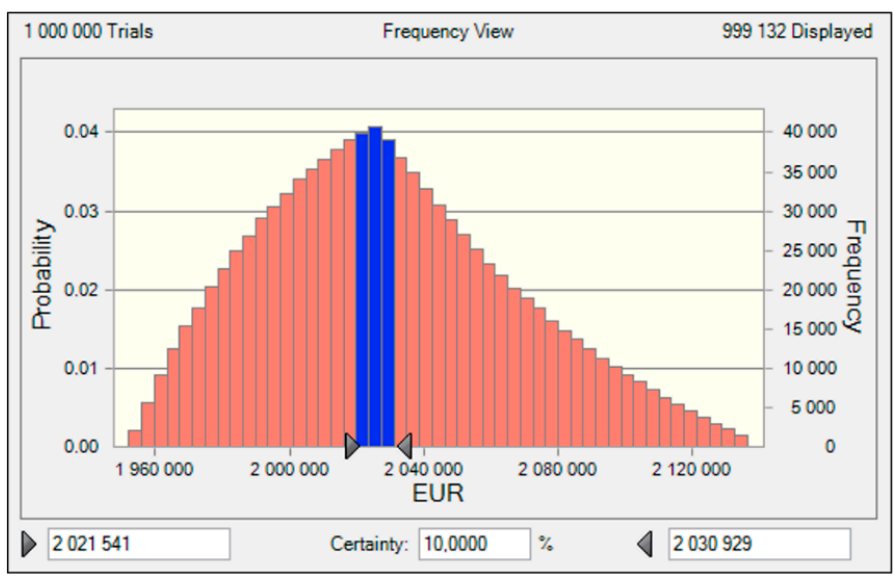

Figure 8. LCCA—-probabilistic approach with certainty level equal to $10 \%$ (own study).

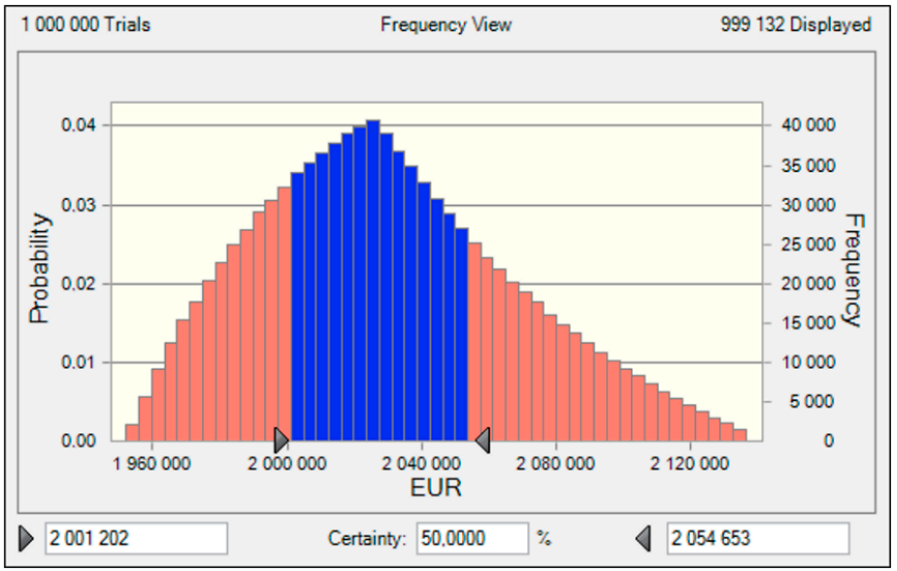

Figure 9. LCCA—-probabilistic approach with certainty level equal to 50\% (own study). 


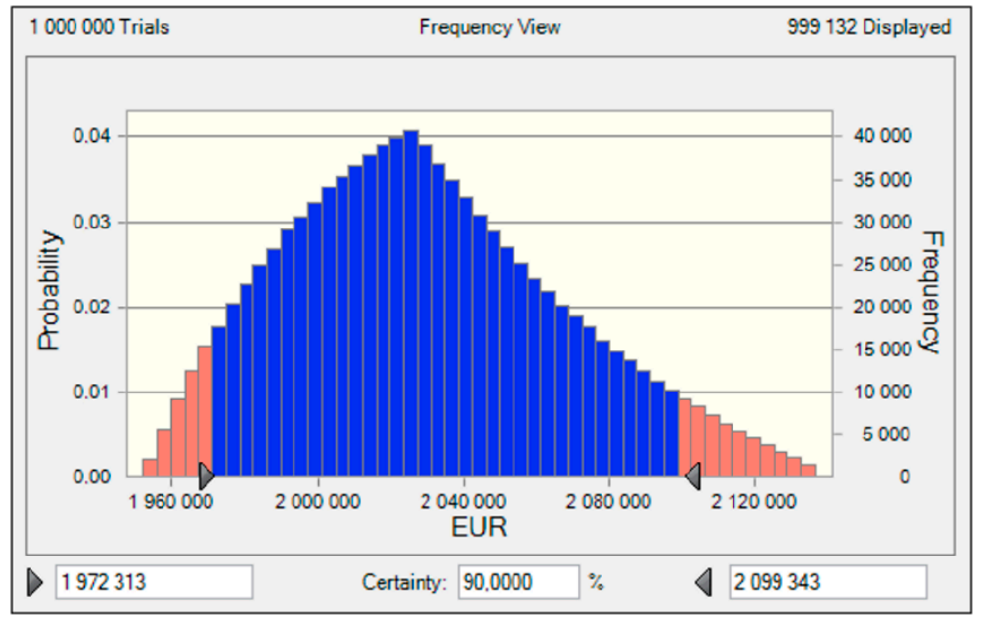

Figure 10. LCCA—-probabilistic approach with certainty level equal to $90 \%$ (own study).

Table 4 in turn, presents a summary of the Monte Carlo analysis results for the standard certainty levels $(10 \%, 50 \%$ and $90 \%$,) indicating differences to the mean value and the median for both boundaries (left and right) on the charts depicted in Figures 8-10.

Table 4. The results of the Monte Carlo analysis (own study).

\begin{tabular}{ccccccc}
\hline \multirow{2}{*}{ Certainty Level } & \multirow{2}{*}{ Boundary } & LCC Results & \multicolumn{2}{c}{ Differences to Mean Value } & \multicolumn{2}{c}{ Differences to Median } \\
& & (in EUR) & EUR & \% & EUR & \% \\
\hline \multirow{2}{*}{$10 \%$} & left & $2,021,541$ & -8077 & -0.398 & -4638 & -0.399 \\
& right & $2,030,929$ & +1311 & +0.065 & +4750 & +0.065 \\
\hline \multirow{2}{*}{$50 \%$} & left & $2,001,202$ & $-28,416$ & -1.400 & $-24,977$ & -1.402 \\
& right & $2,054,653$ & $+25,035$ & +1.233 & $+28,474$ & +1.236 \\
\hline \multirow{2}{*}{$90 \%$} & left & $1,972,313$ & $-57,305$ & -2.823 & $-53,866$ & -2.828 \\
& right & $2,099,343$ & $+69,725$ & +3.435 & $+73,164$ & +3.441 \\
\hline
\end{tabular}

As Table 4 shows, a higher certainty level increases the difference between the LCCA score, the mean value and median according to the probabilistic approach. In the analyzed example, the values of differences to mean value and median were $-2.823 \%$ and $-2.828 \%$ for left boundaries and $+3.435 \%$ and $+3.441 \%$ for right boundaries, respectively.

\section{Conclusions}

The ways in which built structures are procured and erected, used and operated, maintained, repaired and refurbished, and finally demolished, constitute the complete cycle of sustainable construction activities. LCC is a key element in the assessment of environmental sustainability in construction. It provides a tool for the economic evaluation of alternative sustainability options exhibiting different capital, operating costs or resource usage. Based on the comparison studies described above, concerning fuzzy and probabilistic approaches to estimate the life cycle costs of buildings under risk-impact conditions, it can be concluded that the results obtained using the probabilistic approach are consistent with the results obtained using the fuzzy approach, that is the basic approach in the model for the estimation of the whole life costs of buildings. Differences between the results presented in Table 3 for mean, median, minimum and maximum values are equal $-0.122 \%$, $+0.071 \%,+0.035 \%$ and $+0.170 \%$, respectively, with respect to the results obtained by the fuzzy approach . These differences are so small and insignificant that the thesis that the probabilistic approach confirms the validity of the assumptions adopted by the authors of the model for estimating the whole life costs of buildings can be considered as true. 
Moreover, the probabilistic approach complements the model for estimating the whole life costs of buildings with regard to the certainty level as a percentage of likelihood. Figure 7 indicates a sample certainty level value and the LCC result range for the cross-section corresponding to the 0.5 cross-section, according to the fuzzy approach. What was obtained was certainty level at the level of $74.9583 \%$ and in the results range, which is from EUR 1,985,363 to EUR 2,077,267 according to the fuzzy approach.

In addition, it should be emphasized that the probabilistic approach enables the application of analyses recommended by the ISO standard [11] due to the need to conduct an LCCA in the case of uncertainty or risk impact, in the recommendation for the use of statistical techniques, such as Monte Carlo analysis, at a likelihood level of $10 \%, 50 \%$ and $90 \%$. The results of the Monte Carlo analysis for the example described in this paper are summarized in Table 4.

According to the authors, the hybrid application of both approaches to life cycle costs analysis in construction using the author's own model for estimating the whole life costs of buildings, as presented in this paper, can solve the existing problem of performing LCCA in a non-complex way. In the example it is assumed that the life cycle of the building would end with its demolition and the resale of the building plot on which it was built (building life cycle termination of the "from cradle to grave" type). The study is addressed to all stakeholders, but in particular it may be helpful for the owners of buildings, who want to shape the policy of building management in a rational and economic way.

Author Contributions: The individual contribution and responsibilities of the authors were as follows: E.P. and K.Z. made a review of the literature concerning introduction part and selected models for estimating life cycle costs involving risk impact. E.P., D.W. and K.Z. described all assumptions of the original model for estimating the whole life costs of buildings. W.M. and D.W. prepared life cycle cost analysis and compared results obtained by the fuzzy and probabilistic approach. W.M. conducted Monte Carlo analysis with use of Oracle Crystall Ball software. All authors have read and agreed to the published version of the manuscript.

Funding: This research received no external funding.

Conflicts of Interest: The authors declare no conflict of interest.

\section{References}

1. Hajnal, I. Optimisation of Public Building Projects in the Design Phase. Period. Polytech. Archit. 2006, 47, 99-103. [CrossRef]

2. Ruparathna, R.; Hewage, K.; Sadiq, R. Economic evaluation of building energy retrofits: A fuzzy based approach. Energy Build. 2017, 139, 395-406. [CrossRef]

3. Grzyl, B.; Apollo, M.; Miszewska-Urbańska, E.; Kristowski, A. Zarządzanie eksploatacją obiektu w ujęciu kosztów cyklu życia. Acta Sci. Pol. Archit. 2017, 16, 85-89. [CrossRef]

4. Apollo, M.; Siemaszko, A.; Miszewska-Urbańska, E. The selected roof covering technologies in the aspect of their life cycle costs. Open Eng. 2018, 8, 478-483. [CrossRef]

5. Stewart, E.B.; Sahin, O.; Pham, L.; Ekambaram, P.; Stewart, R.A.; Bertone, E.; Flores, J.F.C.T. Resilient Buildings: Informing Maintenance for Long-term Sustainability; Technical Report; Griffith University: Brisbane, Australia, 2018.

6. Zayed, T.M.; Chang, L.M.; Fricker, J.D. Life-cycle cost analysis using deterministic and stochastic methods: Conflicting results. J. Perform. Constr. Facil. 2002, 16, 63-74. [CrossRef]

7. Noor, M.; Aizuddin, N. Whole Life Cycle Costing and Quality Satisfaction: Public Housing Floor Material. Adv. Mater. Res. 2013, 717, 877-883. [CrossRef]

8. Kowalski, D.; Grzyl, B.; Kristowski, A. The cost analysis of corrosion protection solutions for steel components in terms of the object life cycle cost. Civ. Environ. Eng. Rep. 2017, 26, 5-13. [CrossRef]

9. Biolek, V.; Hanák, T. Material life cycle costing of buildings: A case study. In AIP Conference Proceedings, Proceedings of International Conference of Numerical Analysis and Applied Mathematics (ICNAAM), Thessaloniki, Greece, 25-30 September 2017; Simons, E.D., Ed.; AIP Publishing: Melville, NY, USA, 2018; Volume 1978, p. 240013. 
10. Aye, L.; Bamford, N.; Charters, B.; Robinson, J. Environmentally sustainable development: A life-cycle costing approach for a commercial office building in Melbourne, Australia. Constr. Manag. Econ. 2000, 18, 927-934. [CrossRef]

11. ISO. ISO 15686-5.2:2008 Buildings and Constructed Assets-Service Life Planning: Part 5, Life-Cycle Costing; ISO: Genewa, Switzerland, 2008.

12. Hasan, A.; Vuolle, M.; Siren, K. Minimisation of life cycle cost of a detached house using combined simulation and optimisation. Build. Environ. 2008, 43, 2022-2034. [CrossRef]

13. Marszal, A.J.; Heiselberg, P. Life cycle cost analysis of a multi-storey residential net zero energy building in Denmark. Energy 2011, 36, 5600-5609. [CrossRef]

14. Plebankiewicz, E. Kierunki działań zmierzających do obniżenia kosztów w cyklu życia budynków miejskich. In Budownictwo na Obszarach Zurbanizowanych: Nauka, Praktyka, Perspektywy; Halicka, A., Ed.; Politechnika Lubelska: Lublin, Poland, 2014.

15. Ustinovichius, L.; Popov, V.; Cepurnaite, J.; Vilutienè, T.; Samofalov, M.; Miedziałowski, C. BIM-based process management model for building design and refurbishment. Arch. Civ. Mech. Eng. 2018, 18, 1136-1149. [CrossRef]

16. Di Giuseppe, E.; Iannaccone, M.; Telloni, M.; D'Orazio, M.; Di Perna, C. Probabilistic life cycle costing of existing buildings retrofit interventions towards nZE target: Methodology and application example. Energy Build. 2017, 144, 416-432. [CrossRef]

17. Plebankiewicz, E.; Wieczorek, D. Rozmyta ocena ryzyka w cyklu życia obiektów budowlanych. Mater. Bud. 2016, 6, 59-61. [CrossRef]

18. Plebankiewicz, E.; Zima, K.; Wieczorek, D. Quantification of the risk addition in life cycle cost of a building object. Tech. Trans. 2017, 5, 35-45.

19. Wieczorek, D. Fuzzy risk assessment in the life cycle of building object - selection of the right defuzzification method. In AIP Conference Proceedings, Proceedings of International Conference of Numerical Analysis and Applied Mathematics (ICNAAM), Thessaloniki, Greece, 25-30 September 2017; Simons, E.D., Ed.; AIP Publishing: Melville, NY, USA, 2018; Volume 1978, p. 240005.

20. Wieczorek, D.; Plebankiewicz, E.; Zima, K. Model estimation of the whole life cost of a building with respect to risk factors. Technol. Econ. Dev. Econ. 2019, 25, 20-38. [CrossRef]

21. Plebankiewicz, E.; Wieczorek, D. Multidimensional sensitivity study of the fuzzy risk assessment module in the life cycle of building objects. Open Eng. 2018, 8, 490-499. [CrossRef]

22. Plebankiewicz, E.; Zima, K.; Wieczorek, D. Original Model for Estimating the Whole Life Costs of Buildings and its Verification. Arch. Civ. Eng. 2019, 65, 163-179. [CrossRef]

23. Fuller, S.K.; Boyles, A.S. Life-Cycle Costing Workshop for Energy Conservation in Buildings: Student Manual; National Inst. of Standards and Technology (CAML): Gaithersburg, MD, USA, 2000.

24. Menassa, C.C. Evaluating sustainable retrofits in existing buildings under uncertainty. Energy Build. 2011, 43, 3576-3583. [CrossRef]

25. Ammar, M.A.; Zayed, T.M.; Mosehli, O. Fuzzy-based life-cycle cost model for decision making under subjectivity. J. Constr. Eng. Manag. 2012, 139, 556-563. [CrossRef]

26. Ammar, M.A.; Moselhi, O.; Zayed, T.M. Decision support model for selection of rehabilitation methods of water mains. Struct. Infrastruct. Eng. 2012, 8, 847-855. [CrossRef]

27. Połoński, M.; Pruszyński, K. Problematyka ryzyka w projektowaniu realizacji robót budowlanych (cz. 1). Przegląd Bud. 2006, 77, 46-49.

28. Knight, F.H. Risk, Uncertainty and Profit; Courier Corporation: Mineola, NY, USA, 2012.

29. Kaczorek, K.; Krzemiński, M.; Ibadov, N. The problem of choosing risk management methodology at the example of railway construction. In MATEC Web of Conferences Proceedings, Proceedings of XXVI R-S-P Seminar 2017 Theoretical Foundation of Civil Engineering, Warsaw, Poland, 21-25 August 2017; EDP Sciences: Les Ulis, France, 2017; Volume 117, p. 00073.

30. Fregonara, E.; Pattono, S. A sustainability indicator for building projects in presence of risk/uncertainty over time: A research experience. Aestimum 2018, 73, 173-205.

31. Mirkovic, M. The Impact of Failure Types in Construction Production Systems on Economic Risk Assessments in the Bidding Phase. Complexity 2018, 2018, 1-13. [CrossRef] 
32. Siemaszko, A.; Grzyl, B.; Kristowski, A. A Model for Risk Assessment and Management of Construction Projects in Urban Conditions. In Proceedings of the 2018 Baltic Geodetic Congress (BGC Geomatics), Olsztyn, Poland, 21-23 June 2018; pp. 7-11.

33. Meszek, W.; Rejment, M.; Dziadosz, A. Disturbance Analysis and Their Impact on Delays in Construction Process. In IOP Conference Series: Materials Science and Engineering, Proceedings of 2019 World Multidisciplinary Civil Engineering-Architecture-Urban Planning Symposium, Prague, Czech Republic, 17-21 June 2019; IOP: London, UK, 2019; Volume 603, p. 052002.

34. Rogalska, M.; Żelazna-Pawlicka, J. Analysis of the Distribution Influence of the Density of Cost-forming Factors on Results of the LCCA Calculations. Arch. Civ. Eng. 2019, 65, 101-112. [CrossRef]

35. Konior, J. Significance Risks Evaluation of Commercial Construction Projects. Arch. Civ. Eng. 2019, 65, 19-33. [CrossRef]

36. Dziadosz, A.; Rejment, M. Risk assessment in construction project using statistic approach. In AIP Conference Proceedings, Proceedings of International Conference of Numerical Analysis and Applied Mathematics (ICNAAM), Rhodes, Greece, 13-18 September 2018; Simos, T.E., Ed.; AIP Publishing: Melville, NY, USA, 2019; Volume 2116, p. 180012.

37. Leśniak, A.; Janowiec, F. Risk Assessment of Additional Works in Railway Construction Investments Using the Bayes Network. Sustainability 2019, 11, 5388. [CrossRef]

38. Gupta, C.P. A note on the transformation of possibilistic information into probabilistic information for investment decisions. Fuzzy Sets Syst. 1993, 56, 175-182. [CrossRef]

39. Mohamed, S.; McCowan, A.K. Modelling project investment decisions under uncertainty using possibility theory. Int. J. Proj. Manag. 2001, 19, 231-241. [CrossRef]

40. Rębiasz, B. Efektywność i ryzyko projektów inwestycyjnych - rozkłady prawdopodobieństwa czy rozkłady możliwości. Bad. Oper. I Decyz. 2006, 3-4, 113-131.

41. Dikmen, I.; Birgonul, M.T.; Han, S. Using fuzzy risk assessment to rate cost overrun risk in international construction projects. Int. J. Proj. Manag. 2007, 25, 494-505. [CrossRef]

42. Przybycin, Z. Zarządzanie ryzykiem projektów inwestycyjnych. Zesz. Nauk. Wyższej Szkoty Bank. We Wroctawiu 2011, 20, 351-361.

(C) 2019 by the authors. Licensee MDPI, Basel, Switzerland. This article is an open access article distributed under the terms and conditions of the Creative Commons Attribution (CC BY) license (http://creativecommons.org/licenses/by/4.0/). 